\title{
THE EFFECT OF FASTING ON THE LIPOPROTEIN LIPASE ACTIVITY OF RAT HEART AND DIAPHRAGM *
}

\author{
By C. H. HOLLENBERG $\dagger$ \\ (From the Pratt Clinic-New England Center Hospital, and the Department of Medicine, Tufts \\ University School of Medicine, Boston, Mass.)
}

(Submitted for publication February 15, 1960; accepted April 22, 1960)

Recent studies have indicated that the activity of lipoprotein lipase in rat adipose tissue is related to the nutritional state of the animal. Fasting induces a fall in the activity released from surviving tissue by heparin and in the activity of homogenates of adipose tissue, while glucose and insulin in vitro increase the heparin effect on the release of lipase from surviving adipose tissue of fasted rats. Glucose and insulin also prevent the fall in activity that occurs when tissue from fed or fasted animals is pre-incubated in buffer before preparation of the homogenates (1).

Previous observations by Zemplényi and Grafnetter suggest that the lipolytic activity of rat myocardium increases on fasting (2), and since extracts of heart tissue contain lipoprotein lipase (3) it was considered of interest to study the effect of fasting on the activity and release of this enzyme from heart tissue. The possibility that similar activity might be found in another repeatedly contracting muscle, diaphragm, was also explored.

\section{METHODS}

Male albino rats (150 to $200 \mathrm{~g}$ ) were anesthetized with sodium pentobarbital and the heart or diaphragm excised and trimmed, rinsed quickly with Krebs-Ringer phosphate buffer and then sliced or homogenized.

In the experiments in which slices of either heart or diaphragm were used the following procedure was followed. The diaphragm was cut into two approximately $100 \mathrm{mg}$ pieces; each piece was then placed in a separate flask. The heart was opened with scissors and then sectioned with a razor blade into multiple small slices, each weighing $25 \mathrm{mg}$ or less. Two groups of slices, each approximately $100 \mathrm{mg}$ in total weight, were then placed in separate flasks. The time from excision of the tissue until the slices were placed in the incubation me-

* This study was supported by Grants A-1567 and A-612 from the National Institutes of Health, and by a grant from the American Cyanamid Co.

$\dagger$ Medical Research Fellow, National Research Council, Canada. Present address: McGill University Clinic, Montreal General Hospital, Montreal, Quehec. dium rarely exceeded 2 minutes. To one of each pair of flasks was added $125 \mu \mathrm{g}$ of heparin per $\mathrm{ml}$ (Liquaemin, Organon, $10 \mathrm{mg}$ per $\mathrm{ml}$ ). The incubation medium (unless specified otherwise) consisted of 4.5 parts KrebsRinger phosphate buffer, $\mathrm{pH} 7.4,4.5$ parts normal human fasting serum, and 1 part 5 per cent coconut oil emulsion (Ediol, Schenlabs). In all experiments the phosphate buffer contained 5 per cent of human albumin, the albumin having been freed of fatty acids by extraction with an acidified 4:1 isopropanol: heptane mixture (4), washed with absolute alcohol, dried, and dissolved in water with adjustment of $\mathrm{pH}$ to 7.4 with sodium hydroxide.

Incubation was carried out in a Dubnoff shaker at $37^{\circ}$ $C$ under air. At the end of 1 hour the tissue was removed, weighed, and the free fatty acid content of a sample of the medium determined by the method of Dole (4). Incubation of the medium was continued for another hour when the medium was again sampled. The activity of the lipase in the medium was estimated by the change in the free fatty acid content of the medium over the second hour; this was expressed as microequivalents of fatty acid produced per gram of tissue per hour. On occasion, incubation of the medium alone was attended by a small rise in fatty acid content. When this occurred, this change was subtracted from that occurring in the vessels containing tissue.

In experiments in which homogenates were used, approximately $100 \mathrm{mg}$ of heart or diaphragm was minced, weighed, and then crushed in a glass homogenizer containing $5.5 \mathrm{ml}$ of the same medium used in the studies on intact tissue; $4 \mathrm{ml}$ of this mixture was then incubated for 2 hours under the conditions described above. The mixture was kept frozen from the time the tissue was placed in the medium until the start of incubation, except during the brief period required for homogenization. The lipolytic activity was determined by the change in free fatty acid content of the mixture during incubation and this was expressed as microequivalents of fatty acid produced per gram of tissue per hour.

\section{RESULTS}

The release of lipolytic activity from slices of rat heart and diaphragm. The release of lipolytic activity from pieces of heart and diaphragm of fed and fasted rats and the effect of heparin on this activity are illustrated in Figure 1. In each 


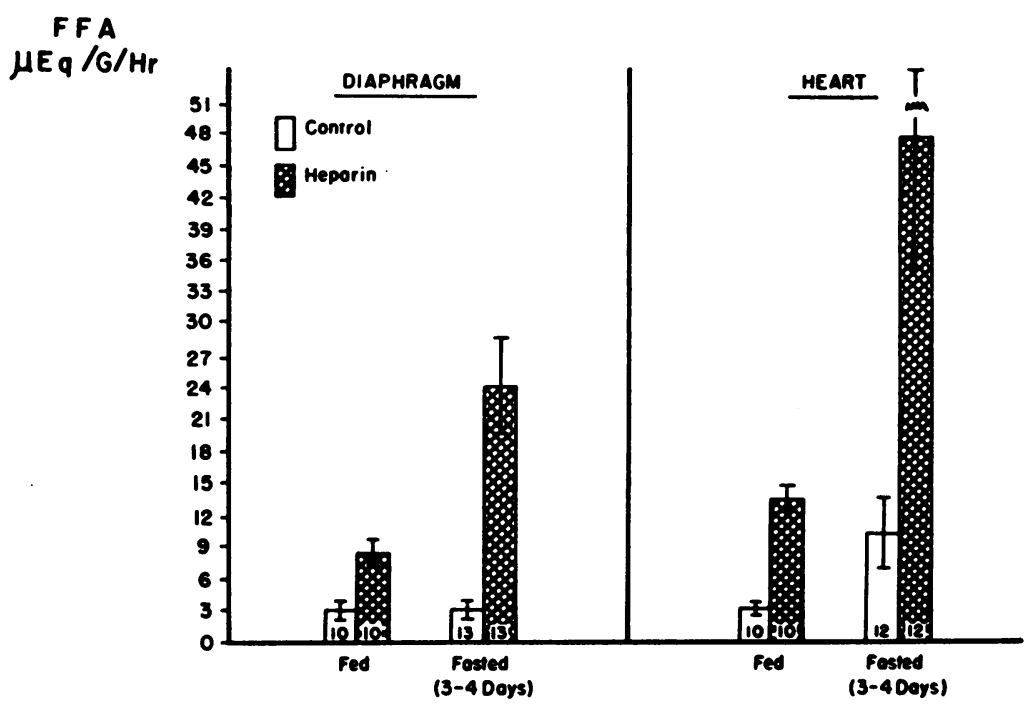

Fig. 1. The Release of Lipoprotein lipase from Slices of RAT heart AND DIAPHRAGM. Statistical analysis: control vs. heparin : $p<0.01$ in each instance. Control fed vs. control fasted heart: $0.05<\mathrm{p}<0.1$. Heparin effect on fed vs. fasted diaphragm: $p<0.01$. Heparin effect on fed vs. fasted heart : $0.01<p<$ 0.05. Brackets: SE. Number of animals indicated at foot of each column in this and succeeding figures.

instance the effect of heparin was to increase the lipolytic activity in the medium, as shown during the second hour of incubation when tissue was no longer present. When the animals were fasted for 72 to 96 hours the heparin effect with both tissues was significantly increased, while a fast of 48 hours produced a smaller change. As reported by Cherkes and Gordon (5), a fasting interval of 24 hours or less did not alter the heparin response. One $M$ sodium chloride, a known inhibitor of lipoprotein lipase (3), substantially reduced the activity that had been released by

TABLE I

Inhibition by $1 \mathrm{MNaCl}$ of lipase released by heart and diaphragm slices*

\begin{tabular}{lc}
\hline \multicolumn{1}{c}{ Tissue } & $\begin{array}{c}\text { Per cent } \\
\text { inhibition }\end{array}$ \\
\hline Fed diaphragm & 70 \\
Fasted diaphragm (3 days) & 96 \\
Fed heart & 88 \\
Fasted heart (3 days) & 94
\end{tabular}

* Two groups of slices from each tissue were incubated separately in a medium of $1.8 \mathrm{ml}$ serum, $0.45 \mathrm{ml}$ albumin and $125 \mu \mathrm{g} / \mathrm{ml}$ heparin for 1 hour. Tissue was then removed and $1.35 \mathrm{ml}$ phosphate buffer added to one flask, and $\mathbf{1 . 3 5}$ $\mathrm{ml}$ of the buffer containing $0.156 \mathrm{~g} / \mathrm{ml} \mathrm{NaCl}$ to the other. After 5 minutes of incubation at room temperature, $0.4 \mathrm{mi}$ of $5 \%$ coconut oil was added to all flasks and the free fatty acid change measured over an ensuing hour of incubation. heart and diaphragm slices from fed or fasted animals (Table I).

These results indicate that a lipase similar to lipoprotein lipase was released from slices of rat heart and diaphragm. It has been demonstrated that heparin added in vitro causes a release of lipoprotein lipase from adipose tissue $(1,5)$, and it is likely that a similar process occurred in the present experiments. It is difficult, however, to attribute the effect of heparin solely to an effect on enzyme release; in experiments using heart tissue from fasted rats, heparin produced a twoto threefold increase in the lipolytic activity of the medium when it was added only after the tissue had been removed. This is analagous to the effect of heparin on partially purified enzyme preparations (3). It is therefore probable that both processes, increased release of enzyme and activation of enzyme in tissue and medium, contributed to the total response to heparin noted.

Lipolytic activity of homogenates of rat heart and diaphrgam. The effect of fasting on the lipolytic activity of homogenates of rat heart and diaphragm is illustrated in Figure 2. The activity of heart homogenates was consistently greater than that of diaphragm while the activity of both tissues increased progressively as fasting was 
TABLE II

The effect of pre-incubation on the lipolytic activity of homogenates of heart and diaphragm from four-day fasted rats*

\begin{tabular}{|c|c|c|c|c|c|c|c|}
\hline \multicolumn{4}{|c|}{ Diaphragm } & \multicolumn{4}{|c|}{ Heart } \\
\hline \multicolumn{2}{|c|}{ Initial† } & \multicolumn{2}{|c|}{ 3-Hour } & \multicolumn{2}{|c|}{ Initial } & \multicolumn{2}{|c|}{ 3-Hour } \\
\hline Serum $\S$ & No serum $\|$ & Serum & No serum & Serum & No serum & Serum & No serum \\
\hline $\begin{array}{r}144 \\
53 \\
76 \\
88\end{array}$ & $\begin{array}{l}93 \\
28 \\
22 \\
23\end{array}$ & $\begin{array}{l}62 \\
26 \\
32 \\
23\end{array}$ & $\begin{array}{l}50 \\
32 \\
27 \\
18\end{array}$ & $\begin{array}{l}273 \\
366\end{array}$ & $\begin{array}{l}130 \\
139\end{array}$ & $\begin{array}{l}108 \\
173\end{array}$ & $\begin{array}{r}65 \\
122\end{array}$ \\
\hline Mean 90 & 42 & 36 & 32 & 319 & 134 & 140 & 93 \\
\hline
\end{tabular}

* Lipolysis expressed as microequivalents per gram per hour.

$\dagger$ Tissue homogenized immediately on removal from animal.

Tissue incubated in phosphate buffer for 3 hours and then homogenized.

$\$$ Serum: the medium consisted of 4.5 parts serum, 4.5 parts phosphate buffer with $5 \%$ albumin and 1 part $5 \%$ coconut oil.

"No serum: the medium consisted of 9 parts phosphate buffer with $5 \%$ albumin and 1 part $5 \%$ coconut oil.

prolonged. The greater effect of heparin when tissue slices from fasted animals were used was thus probably a reflection of the increased activity of lipoprotein lipase in the tissue. These findings are in contrast to those with adipose tissue in which fasting induced a fall in the lipoprotein lipase activity of the tissue homogenates (1).

Since the optimal substrate of lipoprotein lipase is a lipoprotein-triglyceride mixture (6), an attempt was made to characterize the activities of heart and diaphragm homogenates by noting the effect on these activities of omitting serum, and hence lipoprotein, from the medium. In these experiments one piece of tissue was homogenized in the medium described above, while a second piece was ground in a medium of similar composition except for the absence of serum; the total volume of the medium and the concentration of coconut oil was the same in both instances. The results are shown in Figure 3. Addition of serum to the coconut oil substrate increased the activity of heart homogenates from fed and fasted animals

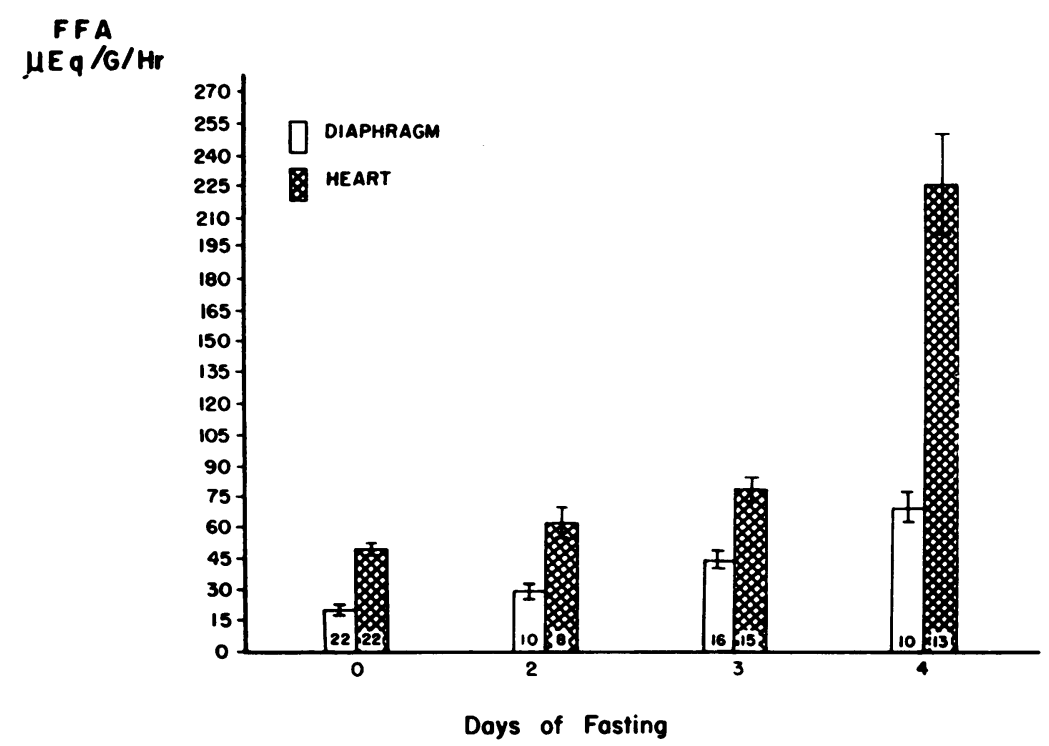

Fig. 2. Lipolytic activity of homogenates of heart and diaphragi. Statistical analysis: (Diaphragm) fed vs. 2-day fast: $0.01<\mathrm{p}<0.05$; fed vs. 3- or 4-day fast: $p<0.01$. (Heart) fed vs. 2-day fast: $p>0.1$; fed vs. 3- or 4-day fast: $p<0.01$. 


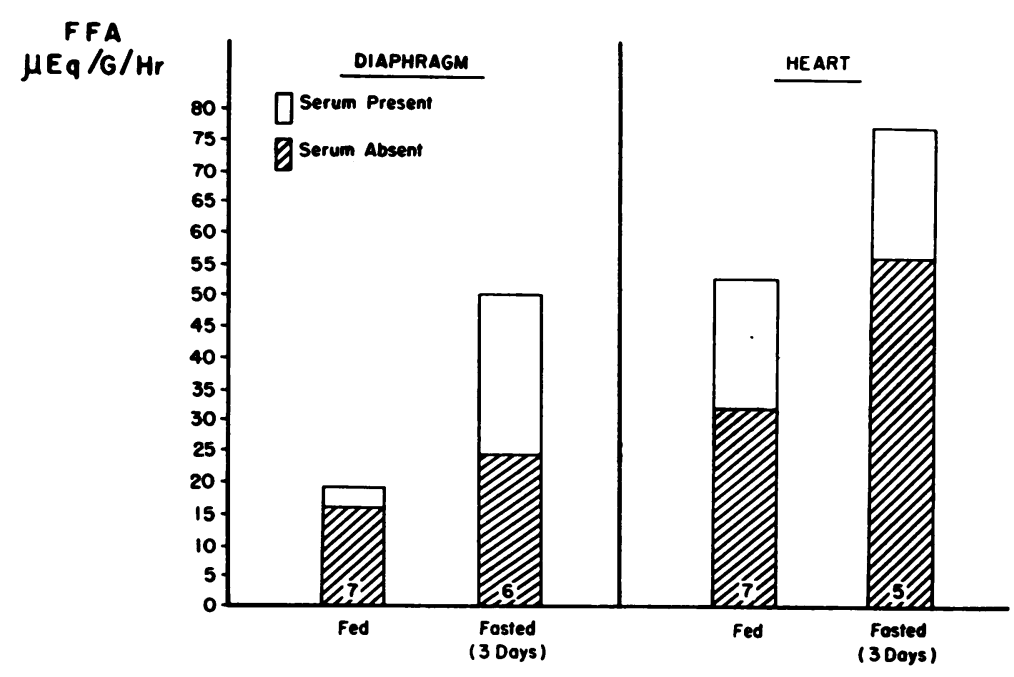

Fig. 3. Lipolytic activity of homogenates of heart and diaphragi WITH AND WITHOUT SERUM IN THE MEDIUM.

and of diaphragm homogenates from fasted rats. It had little effect when diaphragm tissue from fed rats was used. As shown in Table II, the activity of both tissues from 4-day fasted animals fell when the intact tissues were incubated in buffer for 3 hours before homogenizing. At the end of this incubation, heart tissue was still considerably more active with the serum-coconut oil substrate but diaphragm only slightly so.

Inhibition by protamine was studied by adding $900 \mu \mathrm{g}$ per $\mathrm{ml}$ of protamine to a homogenate of tissue in phosphate buffer and albumin. This mixture was shaken at room temperature for 5 minutes and then an aliquot of the mixture was added to serum and coconut oil, the ingredients being present in the ratios previously described.

TABLE III

The effect of protamine on the lipolytic activity of rat heart and diaphragm*

\begin{tabular}{lccccc}
\hline \hline & \multicolumn{2}{c}{ Diaphragm } & & \multicolumn{2}{c}{ Heart } \\
\cline { 2 - 3 } \cline { 5 - 6 } Tissue homogenized in & Fed & Fasted $\dagger$ & & Fed & Fasted \\
\hline Complete medium $\ddagger$ & & 98 & & & 371 \\
Buffer-albumin & 11 & 29 & & 34 & 265 \\
Buffer-albumin§ & 12 & 29 & & 11 & 101 \\
$\quad+$ protamine & & & & & \\
\hline
\end{tabular}
hour.

* Lipolysis expressed as microequivalents per gram per

$\dagger$ Four days.

Incubated immediately at $37^{\circ} \mathrm{C}$.

$\S$ Incubated at room temperature for 5 minutes, remaining medium then added and incubation at $37^{\circ} \mathrm{C}$ commenced.
A control specimen was treated in the same way without protamine. In some instances a third piece of the same tissue was homogenized in the entire medium and incubated immediately. Sampling and incubation were carried out as described for the other homogenate experiments. As demonstrated in Table III, protamine consistently inhibited the lipolytic activity of homogenates of heart tissue prepared from either fasted or fed animals, but its effect on diaphragm was negligible. As is also shown in this table, homogenates of heart or diaphragm from fasted animals rapidly lost activity when allowed to stand for short periods before introduction of substrate.

To determine whether fasted tissue contained factors that might increase the activity of fed tissue, or conversely, whether homogenates of fed tissue would inhibit the activity. of homogenates from fasted animals, the activity of mixtures of tissues from fed and 4-day fasted animals was compared with activity predicted on the basis of the behavior of each tissue alone. The results summarized in Table IV indicate that activation of fed tissue by fasted tissue or inhibition of fasted tissue by fed tissue could not be demonstrated by this means.

\section{DISCUSSION}

The characteristics of the lipolytic activity of homogenates of heart tissue from fed and fasted animals are similar to those noted by Korn in 
TABLE IV

Predicted and observed lipolytic activity of fed and fasted tissues homogenized together

\begin{tabular}{|c|c|c|c|}
\hline \multirow[b]{2}{*}{ Tissue } & \multirow{2}{*}{$\begin{array}{l}\text { No. of } \\
\text { expts. }\end{array}$} & \multicolumn{2}{|c|}{ Lipolysis* } \\
\hline & & Predicted & Observed \\
\hline $\begin{array}{l}\text { Diaphragm } \\
\text { Heart }\end{array}$ & $\begin{array}{l}4 \\
3\end{array}$ & $\begin{array}{c}4.8 \pm 0.7 \dagger \\
12.2 \pm 1.5\end{array}$ & $\begin{array}{r}4.2 \pm 0.5 \\
11.3 \pm 0.3\end{array}$ \\
\hline
\end{tabular}

* Lipolysis expressed as microequivalents of free fatty acid produced. The medium consisted of 4.5 parts serum, 4.5 parts phosphate buffer with $5 \%$ albumin and 1 part $5 \%$ coconut oil.

$\uparrow$ Standard error.

extracts of rat heart tissue (3), suggesting that lipoprotein lipase provides the major portion of the lipolytic activity of heart tissue. The greater effect of heparin when heart tissue from fasted animals was used suggests that the increase in lipolytic activity of heart homogenates with fasting is due mainly to an increase in lipoprotein lipase activity.

The nature of the activity of diaphragm, however, is not so clear. There is undoubtedly some lipoprotein lipase activity present in diaphragm which rises with fasting, as is evidenced by the heparin effect on tissue from fed animals and the increase in this effect with fasting. The failure of the serum-triglyceride mixture to serve as a better substrate than the triglyceride alone when homogenates of diaphragm from fed animals or from fasted animals that had been pre-incubated were used, suggests that in these instances the major activity may be of a type other than lipoprotein lipase. Moreover, no evidence of inhibition by protamine was observed in homogenates of diaphragm as there was just as great a reduction in activity without protamine as with it during the pre-incubation interval. This might be explained by a greater lability of lipoprotein lipase than of the residual activity and by the finding that the latter is not susceptible to inhibition by protamine.

The factors that incluce the changes in lipoprotein lipase activity on fasting in heart and diaphragm remain to be elucidated. Whatever these factors, the changes produced are sufficiently striking to suggest that they may play an important role in the adaptation of the organism to fasting.

The process by which chylomicrons are taken up by various tissues has not as yet been clearly defined. It is possible that, at least in some tissues, hydrolysis of the triglyceride is a necessary accompaniment of tissue uptake. Since the optimal substrate of lipoprotein lipase is a lipoproteintriglyceride complex such as chylomicrons (6), changes in the activity of this enzyme in various areas may well affect the tissue distribution of circulating triglyceride. Recent studies by Bragdon and Gordon (7) have shown that fasting induces in the rat profound alterations in the tissue distribution of labeled chylomicrons. When the chylomicrons were administered following a 20 hour fast, less of the label was found in adipose tissue and more in heart tissue than when fed animals were used. These changes parallel in direction the changes in lipoprotein lipase activity induced by fasting in these two tissues, although they precede the demonstrable change in heart activity by 24 to 48 hours. If lipoprotein lipase aids in the tissue uptake of chylomicrons, the fall in activity of this enzyme in adipose tissue with fasting would permit the fasted organism to divert more of the circulating triglyceride to tissues such as heart where this nutrient could be readily taken up. As prolongation of fasting is associated with a progressive rise in lipoprotein lipase activity in diaphragm and heart, a more extensive removal of chylomicrons from the circulation by these tissues may occur as fasting progresses.

\section{SUMMARY}

Slices of rat heart and diaphragm were incubated for one hour in a triglyceride medium with and without heparin; the slices were then removed and the lipolytic activity of the medium measured over the ensuing hour. Heparin significantly increased the activity in the medium both with tissues from fed or fasted rats, the effect of heparin being greatest when animals fasted for three to four days were used.

Homogenates of heart tissue had greater lipolytic activity than did those of diaphragm, the activities of both tissues increasing progressively with fasting. The characteristics of the activity of heart homogenates were similar to those of lipoprotein lipase while the characteristics of diaphragm differed in certain respects. 
It is suggested that the activity of lipoprotein lipase in various tissues may, in part, determine the tissue uptake of circulating triglyceride. The similarity in the direction of change produced by fasting in the distribution of isotopic label from chylomicrons and in the lipoprotein lipase activity in rat heart and adipose tissues supports this view.

\section{ACKNOWLEDGMENT}

The author is indebted to Dr. M. S. Raben and Dr. E. B. Astwood for their advice and encouragement during this study. Miss Mary Pasciuto provided valuable technical assistance.

\section{REFERENCES}

1. Hollenberg, C. H. Effect of nutrition on activity and release of lipase from rat adipose tissue. Amer. J. Physiol. 1959, 197, 667.
2. Zemplényi, T., and Grafnetter, D. Vliv hladovění a heparinu na lipolytickou aktivitu tkáni. (Effect of fasting and heparin on tissue lipolytic activity.) Cas. Lék. Čes. 1959, 98, 97.

3. Korn, E. D. Clearing factor, a heparin-activated lipoprotein lipase. I. Isolation and characterization of the enzyme from normal rat heart. J. biol. Chem. $1955,215,1$.

4. Dole, V. P. A relation between non-esterified fatty acids in plasma and the metabolism of glucose. J. clin. Invest. 1956, 35, 150.

5. Cherkes, A., and Gordon, R. S., Jr. The liberation of lipoprotein lipase by heparin from adipose tissue incubated in vitro. J. lip. Res. 1959, 1, 97.

6. Korn, E. D. Clearing factor, a heparin-activated lipoprotein lipase. II. Substrate specificity and activation of coconut oil. J. biol. Chem. 1955, 215, 15.

7. Bragdon, J. H., and Gordon, R. S., Jr. Tissue distribution of $\mathrm{C}^{14}$ after the intravenous injection of labeled chylomicrons and unesterified fatty acids in the rat. J. clin. Invest. 1958, 37, 574. 